Byzantines and the description of the "holy war" system, which was supposed to be developed by the emperor, ought to be mentioned (p. 86-88).

The introduction is ended with the notes on the impact of Tactica on the understanding of military issues in modern times: description of inspirations which can be found in the army of the Habsburgs, Prussia during the times of Frederick the Great, Russia during the times of Peter the Great, in whose times the first attempts to translate the work into Russian were taken. Publication of Tactica in the translation of V.V. Kučma was enriched with bibliography (p. 351-359) and an index of personal names, geographic locations and ethnographic names (p. 361-365).

The translation was supplemented with a critical commentary, consisting mainly of ethnographic and prosoprographic information and chronology of major military events. The main purpose of the extended translator's notes was to find relationships and differences between the text of Tactica and the earlier monuments of Byzantine polemological studies. The comment was also necessary because of the assumptions made by V.V. Kučma - he tried to keep the original Byzantine military terminology, and thus avoided translation of many Greek terms.

As was highlighted in the introduction to this discussion, this new publication of Aletheia Publishing House should be considered a work that closes a certain important period in the development of Russian reflection on the Byzantine military. A high level of knowledge, presented by the translator and commentator of Tactica, suggests that the discussed edition will soon become one of the most important texts for followers of V.V. Kučma's work.

Błażej Cecota (Łódź / Piotrków Trybunalski)

\title{
АРСЕН К. ШАГИНЯН, Армения и страны Южного Кавказа в условиях византийско-иранской и арабской власти, Алетейя, Санкт-Петербург 2011, pp. 511.
}

Due to its geographical location, Armenia was for centuries a valuable asset for empires competing for primacy in the Middle East and in Caucasus. From the $5^{\text {th }}$ until the $7^{\text {th }}$ century, the country of Mount Ararat was the subject of a dispute between Sassanid Persia and the Byzantine Empire. The history of this rivalry, as well as the importance of Armenians in the history of Byzantium and Persia, has been fairly well described in the literature ${ }^{1}$. Polish scholarship, too, can take pride in its successes in this field ${ }^{2}$.

${ }^{1}$ It is sufficient to mention the achievements of such researchers as Peter Charanis, Nina G. Garsoïan, Robert W. Thomson.

2 The following researchers should be mentioned: Krzysztof Stopka from the Jagiellonian University (the most significant work to date being: Armenia christiana. Unionistyczna polityka Konstantynopola i Rzymu a tożsamość chrześcijaństwa ormiańskiego $(I V-X V \quad w$.$) ,$ Kraków 2002) and Teresa Wolińska from University of Łódź (eg: Armeńscy wspótpracownicy Justyniana Wielkiego. Dezerterzy z armii perskiej
Unfortunately, the research on the history of Armenia during the time of the Arab invasions and the existence of the Caliphate, first of Umayyads and later of Abassids has remained beyond the mainstream of researchers' interest. This has been gradually changing for several years now, thanks to the efforts of Arsen K. Shahinyan, a researcher from the Institute of History at the State University in Saint Petersburg. He has devoted three books ${ }^{3}$ and several articles ${ }^{4}$ to the

w Bizancjum, PNH 1.2, 2000, p. 5-32; Armeńscy wspólpracownicy Justyniana Wielkiego. Wielka Kariera eunucha Narsesa, PNH 4.1, 2005, p. 29-50).

${ }^{3}$ In addition to the ones discussed in this review, these were: Армения накануне арабского завоевания, СПб 2003; Закавказве в составе Арабского Халифата, СПб 1998.

${ }^{4}$ Among others: Арабские наместники и правители Арминийи при "Умаййадах , $\mathrm{B}(\mathrm{O})$ 3, 2009, р. 52-59; Государственные налоги Арминийи, ИФЗРА 2 (181), 2009, р. 1-10; Формирование Великого княнества 
issue of Arab control over Armenia. The work which is the subject of this review was the basis for conferring a $\mathrm{PhD}$ degree in history to Arsen Shahinyan in 2010.

The dissertation is divided into two parts. In the first chapter (Armenia and South Caucasus countries under the rule of Byzantium and Persia in 5th-7th centuries: the establishment of the Armenian autonomy and sovereignty, $\mathrm{p}$. 44-220) the author described the history of Armenia, Kartli and Albania from their subordination to the Byzantine Empire and Sassanid Persia (p. 44-85), through obtaining autonomy and full independence due to Arab invasions in mid-seventh century, when Armenia was in the sphere of interests of not only the Empire and the Caliphate but also of the Khazar Khaganate (p. 86-131), to the loss of sovereignty and taking of power by Arabs in the beginning of the $8^{\text {th }}$ century (p. 121-157). The following subsections are devoted to socio-political, economic and religious-ideological issues (p. 157-199). The first part of the work ends with considerations concerning the origins of the institution of the Armenian Ishkhan and the legal and political basis for the existence of the independent Armenian Principality in middle of the $7^{\text {th }}$ century ( $\mathrm{p}$. 199-220).

The second part (entitled Armenia and the South Caucasus countries under the rule of

\footnotetext{
Армянского на территории арабской провинции Арминийа, ВСПУХ 1, 2009, p. 170178; Армения и Арминийа в составе Аббасидского халифата во второй половине VIII и в начале IX века, ВСПУХ 3, 2008, p. 75-91; Формирование автономных Багратидских княжеств на территории арабской провинции Арминийа, ВСПУХ 2, 2008, p. 127-140; Армения и Арминийа в составе Умаййадского халифата, ВСПУХ 1, 2008, р. 139-155; Первые намествия арабов на Армению и ответные походы армяновизантийских отрядов, ИФЗРА 2 (175), 2007, р. 224-235; Первые восстания в Армении и Арминийи против власти Арабского халифата (новые хронологические уточнения), ВЕУОН 2007, 2 р. 105-114, Национальная (миграционная) и религиозная политика Арабского халифата в Армении и Арминийи, Эч 10, 2007, p. 24-38.
}

Arabs in $8^{\text {th }}-9^{\text {th }}$ century: liquidation of the Armenian sovereignty, preserving and extending internal autonomy, p. 221-445) is divided into eight subsections. The first two relate to functioning of Armenia and the Arab province of Arminiya under the rule of caliphs of the Umayyad and the Abbasid dynasties (p. 221-274). In the next section, the author described the formation process of autonomous Christian principalities and Muslim emirates within the mentioned province of the Caliphate (p. 274-313). The description of the history of Armenia (as well as Kartli and Albania) under the rule of Arabs ends with the section on the collapse of the real power of the Abbasids and the obtaining of independence by new Armenian sovereign dynasties, among which the first position was taken by the Bagratid dynasty at the expense of the ancient Mamikonian family (p. 313-338). The historical description is completed with the subsections presenting issues such as: administrative policy of the Arab caliphs towards Armenia (p. 338357 ), religious relations and the phenomenon of the exodus of Armenians to the territories of the Byzantine Empire at the simultaneous migration of Muslims to Armenia (p. 357-381), social and economic issues (p. 381-426). This part of the work is ended, similarly to the first section, by a subsection on the genesis of the ishkhanat institution of the ishkhan of Armenia (prince of princes) and the emergence of the Autonomous Grand Duchy of Armenia in the $9^{\text {th }}$ century (p. 426-445).

The analysis contained in the main text is supplemented with a reliable source-based introduction including relics of Armenian, Arab and Persian literature, less known to the academics dealing with ancient Byzantium, together with a list of critical editions and translations into the congress languages (p. 10-43); tables listing all Arab viceroys (including the ones established for the first time in this publication) of the so-called northern provinces and the Arminiya province (p. 469-472), an extensive bibliography (p. 475$500)$ together with six maps showing national borders on the territory of Armenia in the years 530-591 and 591-630, in the second half of the $7^{\text {th }}$ century, in the 8th century, in the first half of the 9th century and in the years 856-886. 
In the presented book Arsen Shahinyan introduced a new concept of the development process of the independence of Armenia and associated Kartli and Albania in the end-period of the domination of the Byzantine Empire and Sassanid Persia, as well as the height of the power of the Islamic Caliphate under the rule of Umayyads and Abbasids. It is at this point that I would like to draw your attention to some original hypotheses of his.

According to the analysis presented by A. Shahinyan, it was due to the 25-years' war between Persia and Byzantine Empire in the beginning of the $7^{\text {th }}$ century that Armenians managed to achieve political autonomy around the year 630 and retain it under the rule of two zoravars elected during conventions of nakharars (accepted then by the emperor) - of Mzhezh Gnuni (630-637) and Davit Saharruni (637-641). The essence of the autonomy consisted of enabling the members of the council, composed of the representatives of the Armenian aristocracy, mentioned above, taking critical political decisions. A similar process can also be observed in culturally- and geopolitically-related smaller Caucasus countries, such as Lazica, Kartli or Albania (p. 84-85).

The career of Theodore Rshtuni seems to be a consequence of these early successes of the Armenian upper class, who started at the position of a marzban in the Persian part of Armenia and gained independence in 639/640 thanks to the Arab conquest of Sassanids and then extended his domination to the Armenian territories remaining under the Byzantine protectorate in the $730^{\mathrm{s}}$. According to a thesis of a researcher from Saint Petersburg, Rshtuni managed to take power over the entirety of Armenia, including the territories belonging to Cilician Armenia, with the access to the Black Sea, in 641 . The next ten years were a period of maneuvering between the Empire and the Caliphate, which was ended, according to A. Shahinyan, with the recognition of the principality of Theodore by the Arabs in 652, and even granting rights of control over Albania and Kartli in the next year (p. 131). The researcher from Saint Petersburg indicates that Muslim sources, according to which Armenia was finally con- quered by Arabs in the fifties of the century, are too rashly recognized as reliable. He emphasises that none of the Armenian sources confirm this hypothesis and there is no information on leaving garrisons in Armenian towns in the Muslim sources, which was a traditional procedure in the case of the rule of caliphs over a given territory. All this indicates the temporary nature of the effects of Arab victories (p. 130). The possession of autonomy by the Armenians is confirmed by the events from the eighties of the $7^{\text {th }}$ century, when, using the civil war in the Caliphate, the Duchy, together with subordinated Albania and Kartli, gained total independence (681-687). Perhaps this independence would have lasted longer if the Khazar Khaganate, which tried to dominate Armenia by organizing two armed interventions (in 681 and 685 according to A. Shahinyan), had not been sufficiently active to provoke an agreement between the Byzantine Empire and Caliphate establishing an Arab-Byzantine condominium in the principality (p. 140-150). Armenia finally lost its independence at the beginning of the $7^{\text {th }}$ century due to the military expedition of Muhammad ibn Marvan. Thus, the researcher from Saint Petersburg rejects the accepted hypothesis concerning the conquest of Armenia by Arabs, according to which it was conquered in the middle of the $7^{\text {th }}$ century, and moves this date half a century later to the years 701-702 (p. 156-157). What is more, he shows that the Armenian uprising associated with the Arab invasion lasted much longer than it was assumed before (the fight lasted three years, from 702 to 705 , and not one year - p. 223-230).

In the second part of the dissertation, the author managed to determine the names of five viceroys of the Arab province of Arminiya, unknown until now; he based this information on numismatic sources, due to lack of the relevant information in the written sources (p. 249-251; 268-273). He also presented evidence according to which the second anti-Arab uprising in Armenia, which was traditionally dated to $747-$ 750 , lasted much longer; in fact from 744 to 752 (p. 251-256). It is in the main part of the second chapter of the dissertation (p. 274-338) that the author presented the process of regaining independence by the Armenian duchies under 
weakening power of Abbasid caliphs. However, already in the thirties of the 8th century the Arabs had to make some concessions to local elites, due to the risks from the Khazar Khaganate, by appointing Ashot Bagratuni as an ishkhan, i.e.a prince, of Armenia (p. 239-240) but it was only at the beginning of the $9^{\text {th }}$ century that Bagratids managed to obtain full autonomy under the leadership of Ashot IV Msaker. In the middle of the $9^{\text {th }}$ century there were several independent small states on the territory of Armenia, Albania and Kartli, including seven associated with the Bagratid dynasty and three Arab Emirates (Shirvan, Tiflis and Arzan). Suppression of the Armenian uprising in the years 850-855 did not halt, and even sped up, the process of decentralization of the power of the caliphs over the Caucasus province - after the intervention of the troops of the Caliphate under Bugha al-Kabir (852-855), a dozen more Muslim states were created within a period of several years; such domains as those of the Hashimids and Sulamids or independent emirates of Arjish, Barkri and Khilat were established. At the same time, the prerogatives of the ishkhac of Armenia were expanded; the position was occupied by Ashot V Bagratuni since the sixties of the $9^{\text {th }}$ century. In fact, the Armenian superior prince, approved by the caliph, took over all the privileges held by viceroys of the Arminiya province so far. The last part of this section of the dissertation was devoted by the author to the discussion of the efforts made by Ashot in order to centralise divided Armenia under his power, which ended in sacred legitimization of his reign with the ceremony of coronation. A. Shahinyan poses an entirely new hypothesis concerning dating this event, concluding that the coronation of Ashot took place between $19^{\text {th }}$ April and $29^{\text {th }}$ August 886 (p. 325-328).

While the main topic is the issue of obtaining and maintaining autonomy by the Armenian nakharars, the author also raised a number of non-core issues, above all religious and social ones. Among others, he discussed the activity of the Armenian Catholicoi and their contacts with the Syrian patriarchs (e.g. at the Union Council in Manzikert in 725) or the Byzantine attempts to incorporate the Armenian Church into Chalcedonian Oikumene; in this context the at- tempts of the Patriarch of Constantinople Photius should be emphasized (p. 357-359). A lot of space is devoted to considerations concerning the Paulicians and the activities of the Catholicos directed against this heresy (p. 359-366). Because of the new proposals, the importance of reconstructing the families of nakharars, both in the Byzantine-Persian (p. 158-163) as well as the Arab period (p. 158-163), becomes apparent. It is my view that that the considerations on tax issues are very important as well, especially of jizya and haraj (p. 393-407). The author convincingly argues that the financial burdens imposed on Armenia, although burdensome for the local population, were not different from the corresponding amounts imposed in other parts of the Islamic Caliphate. The analysis of the economic development of the province of Arminiya prompted the author to challenge the thesis about the economic collapse of Armenians under the rule of the Arabs (p. 426). Researchers interested in the period of the Arab conquests will certainly focus on those fragments in which A. Shahinyan publishes the translated texts of agreements, preserved in Arab sources, which were put in place by military leaders and residents of Caucasian towns. Such agreements are an interesting comparative material when set beside similar, and much better known, documents from Syria or Egypt (e.g. p. 124-125).

Unfortunately, the scope of the subject and the grand scale of the undertaken work meant that Arsen Shahinyan did not avoid certain errors. In some parts, the reader will be surprised to notice elements bringing nothing to the analysis of the main issues. For example, it seems difficult to understand why the detailed description of the Arabic conquest of Byzantine Syria was included in the dissertation (p. 88-95). It can also be observed that the author sometimes favours sources of Armenian provenance. He admitted that he knows Greek sources only through translations (p. 29). However, this should not be a reason to ignore them. It seems that this is what happened in the fragment devoted to the Byzantine administration in Armenia at the end of the 6th century, which A. Shahinyan bases almost exclusively on the text of the $9^{\text {th }}-10^{\text {th }}$ century Hovhannes 
Draskhanakerttsi (p. 68), without any reference to the literature. The lack of the "Byzantine perspective" is also visible in parts devoted to Persian and Arab victories over the Byzantines - the author repeats outdated hypothesis concerning the alleged impact of the "dissatisfaction" of Syrian and Egyptian Monophysites or Jews on the defeat of Byzantine Empire in the two Middle Eastern provinces (p. 74-75, 88). It is much more surprising if we consider that one of the main researchers of these issues, who created new hypotheses rejecting these interpretations, is a Russian scholar dealing with Byzantium, Mikhail V. Krivov ${ }^{55}$.

${ }^{5}$ М.В. Кривов, Отночение сирийских моно-
Despite the remarks made above, the work of Arsen Shahinyan should be considered as one of the most important recent studies of the history of medieval Armenia. It will be particularly helpful for researchers working on relations of the Byzantine Empire with Sassanid Persia and the Arab Caliphate, mainly due to its original attitude towards the history of the Caucasian countries of the $6^{\text {th }}$ to $9^{\text {th }}$ centuries based on Armenian, Persian and Arab sources.

Błażej Cecota (Łódź / Piotrków Trybunalski)

биситов к арабскому завоеванию, ВВ 55 , 1994, p. 95-103.

\section{ТАТянА СЛАвовА, Славянският превод на Посланието на патриарх Фотий до княз Борис-Михаил [Slavic translation of the Letter of Patriarch Photios to Prince Boris-Michael], Университетско издателство „Св. Климент Охридски“, София 2013, pp. 344 [= История и книжнина].}

The monograph by Tatiana Slavova, released by the University of Sofia Publishing House as the thirteenth volume of the series "История и книжнина", provides an extensive multi-faceted study of the Slavic version of the letter that the Constantinople Patriarch Photios sent to the then ruler of Bulgaria, Boris I (Michael), in the ninth century (probably between 864 and 866) regarding the latter's adoption of the Christian religion. This document, preserved in a number of manuscript copies, has been translated over the centuries into a number modern languages (including Bulgarian, Greek, French, English, and Russian), it has had many editions, and has been a subject of numerous published studies (the unflagging interest it continues to provoke among scholars is evidenced by the fact that many publications on the topic have been written and released in the last thirty years). This publication includes a critical edition of the Slavic version of both parts ${ }^{1}$ of the letter,

\footnotetext{
${ }^{1}$ The letter by Photios consists of two parts, the first devoted to the Christian dogmas, while the second discusses the responsibilities of a Christian ruler to his subjects (cf. Introduction to the edition, p. 5).
}

developed based on examination of 8 complete Ruthenian copies of the text dated from the sixteenth until eighteenth centuries, as well as four abridged ones and one old print dated 1644 . The edition itself has been set in an appropriate historical context and enriched, in addition to the textological investigations, with the study of the language of the text, which constitutes the only source that makes dating the translation possible $^{2}$.

The publication consists of eight chapters, which is complemented by a list of abbreviations, a list of references, and an abstract in the English language.

In the first chapter, entitled Ръкописната mрадиนия [Manuscript Tradition] (p. 9-28), the author focuses first on the existing Slavic editions of the letter and manuscripts on which they were based, presenting their archeographic data in detail (p. 9-20), followed by the codicological characteristics of the manuscript РГБ, Ф. 178, № 3112 (the oldest complete copy of the text of Photios, made in the first quarter of the sixteenth century), which served as the basis of

\footnotetext{
${ }^{2}$ The author mentions it in the Introduction, p. 8.
} 